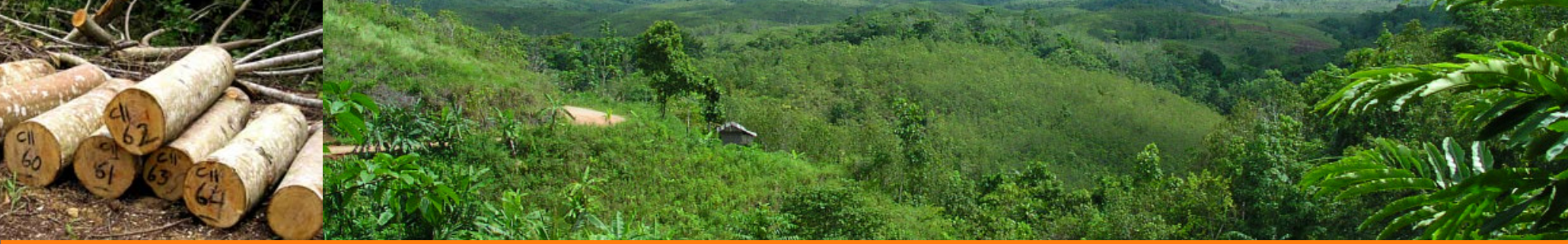

No.5, September 2004 $=$ Decentralisation Brief

\title{
Continued Marginalisation of Under Privileged Communities: Forest Management Following Decentralization in Sintang, West Kalimantan
}

By Gusti Z. Anshari, Syarief Alqadrie, Tri Budiarto, Ngusmanto, Erdi Abidi, Siân McGrath, Zulkifli and Afifudin

\section{Introduction}

Under Indonesia's decentralization program, district governments were officially authorised between 1999 and 2002 to issue small-scale logging concessions for less than 100 ha on state forest land. District heads (Bupatis) all over West Kalimantan responded with policies to regulate the issuance of local permits, known as $\mathrm{HPHH}$ 100 ha permits. The central government revoked the district's right to issue permits in 2002. In West Kalimantan, the Bupatis continued to extend existing permits. The last permit extension was granted at the end of 2003.

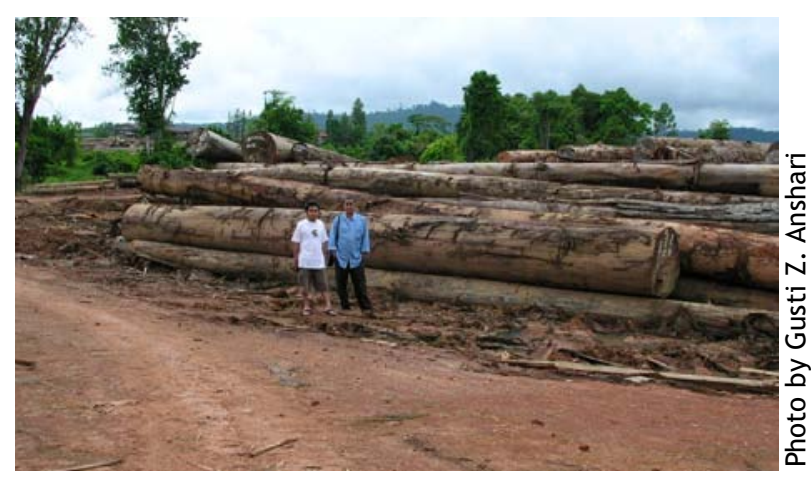

Of all the permits available after decentralization in West Kalimantan, the HPHH 100 ha policy was the only one to stipulate direct local community involvement and profit-sharing as a condition for receiving a permit. The permits were intended to increase the well-being of poor and forest-dependent communities. Although the district policy regulating these small-scale HPHH permits had stronger provisions for community benefit-sharing than any other permit type; its success was ultimately limited for two main reasons.

First, the policy was limited to a small proportion of the forest estate in each district. As is shown in the table below, this policy applied on only $2 \%$ of forest land in the province.

The second limitation was the hasty and exclusive process for designing and implementing the policy. Our study in Sayan, a sub-district of Sintang District in West Kalimantan showed how the process limited opportunities for local, forest-dependent communities to participate in the development and get real benefits from the implementation of this policy.

Table 1. Number of permits in West Kalimantan in 2003.

(Source: Budiarto et al., 2004)

\begin{tabular}{lcrr|}
\hline Permit Type & $\begin{array}{c}\text { Number } \\
\text { Issued }\end{array}$ & Area (ha) & $\begin{array}{c}\text { Total Forest } \\
\text { Area* }\end{array}$ \\
\hline Centrally-Issued Permits & & & \\
\hline 1. HPH (privately owned) & 19 & $1,320,468$ & 28.02 \\
\hline 2. HPH (state-owned) & 6 & 784,650 & 16.65 \\
\hline 3. Community-based permit & 1 & 16,490 & 0.35 \\
District-Issued Permits & & & 3.06 \\
\hline 4. Bupati-issued IUPHHK & 9 & 144,050 & 2.00 \\
\hline 5. Bupati-issued HPHH 100 ha & 944 & 94,400 & \\
\hline
\end{tabular}

The district regulation was drafted and enacted so quickly that there was not enough time for any public consultation. Nor was there time to consider the best way to promote socio-economic development under the new policy. People felt that the final policy was strongly influenced by local and national elites, especially centrally based commercial investors. The eligibility criteria

*assuming a total forest area of 4,711,785 (Provincial Forestry Office, 2003) 
were too exclusive and the policy did not provide for fair profit-sharing agreements between local communities and commercial operators.

The problems were very similar to those experienced with the central government's HPH policy. The procedures were inadequate for allocating suitable forest areas and setting boundaries for the small IPHH 100 ha concessions. There was also a failure to regulate concession management to minimize environmental degradation; to keep logging activities within the prescribed boundaries; and to enforce legal obligations to rehabilitate or convert the land after it was logged out.

Since 1999, the Ministry of Forestry's response to its new obligations under the national framework for decentralization has resulted in an overlapping system of central, provincial and district forestry management. Communities have continued to be economically marginalized on all types of concessions, but in the wake of reforms introduced under decentralization and reformasi their confidence has increased. This has meant that they have begun to make their own demands for fair compensation or direct benefits from forest exploitation.

Yet, although some community members have received a small share of the profits from $\mathrm{HPHH} 100$ ha concessions, these have not been equitably distributed. The most marginalized ethnic groups, women and in-migrants received little or nothing. Local powerful elites were the main beneficiaries. Once communities were given the opportunity to access financial benefits, and their rights were given limited legal recognition via the permit system conflicts also increased inside communities, and between communities and concession operators.

This policy brief analyses the impacts of the HPHH 100 ha policy when it was active in Sintang district, West Kalimantan. The central government has now revoked this permit system. However, this should be used as an opportunity for district governments to work with the centre to rationalize the entire permit allocation system, and to devise a more equitable and sustainable national framework that will return more benefits to local people. We hope the lessons learned from our research can help inform future policy development.

\section{The HPHH 100 ha Policy Formulation in Sintang District}

Following decentralization, the Sintang district authorities felt it was important to demonstrate their commitment to "people-based-policies", so they introduced the HPHH 100ha policy extremely quickly. The policy was explicitly aimed at promoting economic development to benefit local communities.

Decree No. 19, regulating Sintang's HPHH 100 ha permit system, was drafted by the district Forestry Office (Dinas Kehutanan) and submitted to the Bupati. Although a Bupati's decree does not require any public consultation, the Bupati did submit the draft to the district parliament (Dewan Perwakilan Rakyat Daerah), for their informal consideration. On 30 November 1999, the DPRD gave their informal support to the policy ${ }^{1}$, and the decree was already operational by December 23, $1999^{2}$.

Some local stakeholders felt the decree was pushed through very quickly because local elites, certain members of the DPRD, and commercial investors stood to gain a lot from the policy. The public was not consulted. No time was allowed to accommodate wider public interests, nor anticipate how the policy would meet its objective of promoting local community development.

\section{SK Bupati 19/1999: Stipulations on Access to, and Protection of Forest} Resources

The Bupati's decree (SK Bupati No. 19/1999) ${ }^{3}$ states permits will only be granted to cooperatives, or Indonesian individuals and legally established private companies proposing to manage the concession in partnership with local communities. To be eligible, local communities must be legally established as a farmers' group (KUT) and must demonstrate traditional ownership rights over the forest area. However, the regulation does not define "traditional ownership rights", or how they should be proved. In practice, only communities able to prove they have ancient "damar tebok" rights have been considered eligible.

"Damar tebok" rights are held by communities with usufruct (collection) rights to harvest resin in natural forests. The rights did not traditionally confer ownership, just collection rights - traditionally recognized by the existence of holes bored in the stems for tapping resin. Damar tebok rights can be established by acknowledgement from the village elders, and receipts of duty paid by resin tappers to the Dutch Colonial administration.

Resin tapping ended a long time ago, but damar tebok rights have been revived since the HPHH 100 ha permit policy was introduced. Damar tebok rights were used as a legal mechanism to legitimize communities' claims to own forest areas for HPHH 100 ha concessions.

Traditionally, access to non-resin producing trees was open to other communities and individual members without damar tebok rights. However, establishing ownership based only on damar tebok rights has provided sizeable benefits for the limited number of people who can prove they tapped resin during the Dutch Colonial era. This means other communities, especially the poorest ethnic groups and in-migrants, 
have no right to apply for a HPHH 100 ha permit.

The Bupati's decree provided for environmental protection and boundary management, but monitoring and enforcement were insufficient due to poor capacity and too few personnel. The decree states that HPHH 100 ha permits cannot be allocated on areas already allocated to centrally issued large-scale, large-scale HPH concession or Timber Utilization Permits ${ }^{4}$, (ljin Pemanfaatan Kayu - IPK ${ }^{5}$.

The Bupati's decree also obliges the holder to replant the same number of trees harvested ${ }^{6}$. Timber harvesting on HPHH 100 ha concessions must be carried out manually and/or semi-mechanically using traditional skid rails (jalan kuda-kuda) and/or small engines used to drag logs (lokomotif) ${ }^{7}$.

\section{Permit Applications}

The District Forestry evaluates applications in conjunction with the District Development Planning Agency (Bappeda). The evaluation includes checking the applicant's legal status, the area proposed within the context of the district's spatial plan, and the existence of nearby villages and communities. The Forestry Office then makes recommendations to the Bupati, who has the final authority to grant a permit. The process is almost entirely controlled by the district Bupati and relevant line agencies ${ }^{8}$, with very little opportunity for local people to participate in decisions about key issues such as the suitability of area locations or the eligibility of applicants.

\section{Permits Granted}

The HPHH 100 ha system offered districts one of their first direct opportunities to control resource exploitation and generate local revenue from forests. Whilst the policy was active (1999-2002), a total of 944 permits were issued in West Kalimantan. Almost all these permits were issued in our two study districts, Sintang (464 permits), and Kapuas Hulu ${ }^{9}$ (335 permits).

Many district heads in West Kalimantan justified the high number of HPHH 100 ha permits they issued by saying the time had come for local people to enjoy the benefits from their own forests. This policy was seen as one way to address the inequities of the New Order regime, which channeled forest benefits to central government authorities and a few giant timber conglomerates from Jakarta. However, local people felt district authorities and elites dominated the new policy's design and implementation to serve their own interests.

Local elites approached HPH concessionaires to broker profit sharing and management partnerships in the name of local communities. The large concessionaires were happy to take advantage of these partnership opportunities. It provided them with sources of cheap timber. As HPHH 100 ha areas were located close to,

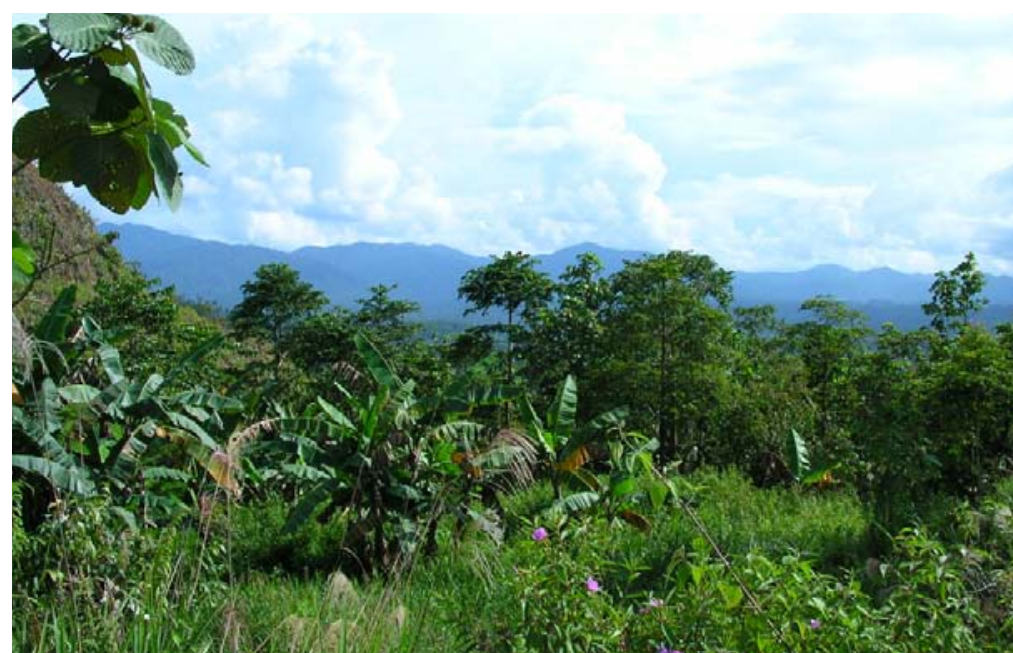

and often overlapped HPH areas, it was also one way to reduce the potential conflict with local communities caused by unclear boundaries.

Although local communities were legally entitled to a share of the benefits, our study shows that the average partnership with HPH concession holders ${ }^{10}$ did not benefit the poorest community members. The lion's share of benefits went to local elites and HPH entrepreneurs, and to timber processing companies. Some HPH concessionaires who had stopped operating either because their permits had been suspended for various violations; or because of conflicts with local communities, also reportedly took advantage of the $\mathrm{HPHH} 100$ ha concession system to resume logging.

\section{Implementation Problems}

\section{Overlapping Boundaries and Property Rights}

Procedures for determining boundaries, surveying timber resources, and identifying suitable areas before issuing permits were inadequate. The District Forest Office should conduct surveys ${ }^{11}$, but area and boundary selection were based on "paper exercises". There was no on-the-ground surveying, and little coordination between the three levels of government responsible for overseeing different concession types.

Consequently, many HPHH 100 ha areas overlap with $\mathrm{HPH}$ concessions, production forests and protected areas. There were also cases where more than one $\mathrm{HPHH}$ permit was issued for the same area. Inadequate surveys often trigger local conflicts. For example: conflicts between Nanga Sayan villagers and neighbouring communities in Mekar Pelita village and Madya Raya village started because each community felt they had had customary rights to the area granted under a HPHH concession. The customary boundaries between the villages' respective forest areas have yet to be settled. Customary boundaries are inconsistent with the administrative boundaries applied by the Soeharto administration. However, administrative boundaries are still used for official planning purposes.

HPHH 100 ha concessions have also overlapped with 


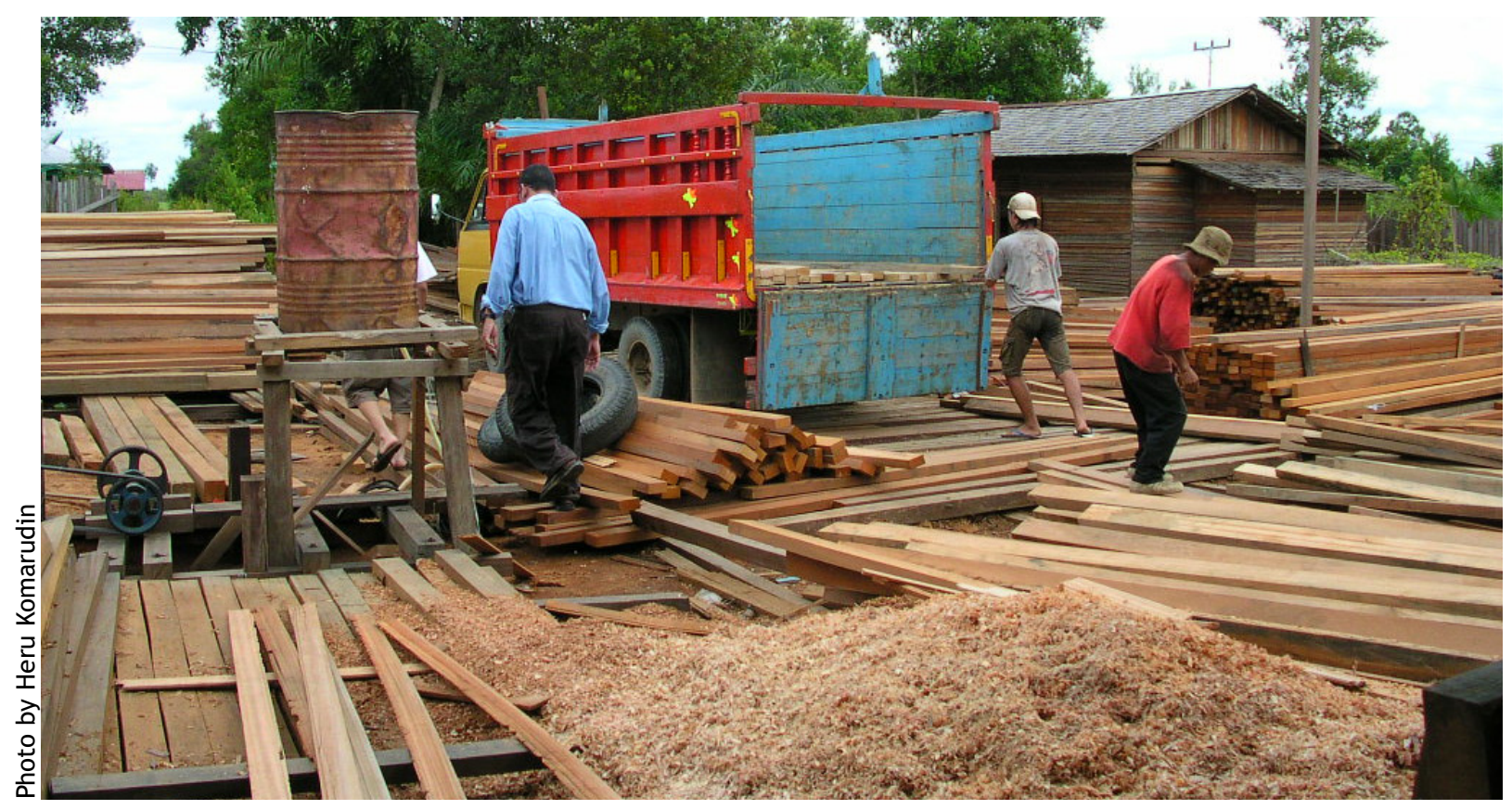

protected areas. The provincial Forestry Office of West Kalimantan estimates about 30\% of HPHH areas are within protected forests. This contravenes the national and the district's own policies ${ }^{12}$ on area selection.

\section{Inadequate Mechanisms for Ensuring Equitable Distribution}

Until mid April 2004, rents and levies (PSDH and DR) payable by HPHH 100 ha permit holders were neither reported nor submitted to the central Ministry of Forestry by many districts in West Kalimantan. Instead they were held in the district governments' accounts, in accordance with special provisions for revenue collection included in the districts' policies ${ }^{13}$. However, these district policy provisions contradict national legislation on payment mechanisms for nontax state revenues and fund transfers ${ }^{14}$. National policy states that PSDH $(\mathrm{IHH})$ must be paid to the Ministry of Forestry, and the Ministry of Finance should regulate these transfers. Instead the districts instructed concessionaires to pay their taxes and fees directly to the district; then made no transfers to the central administration.

Local district governments argued they were withholding payments as an "expression of their disappointment" with the Ministry of Forestry's policies on distributing shared forest revenues. The district authorities believe that PSDH and DR funds previously returned from Jakarta were $40 \%$ below what the district should have received ${ }^{15}$.

The KUT (farmers' groups) who got HPHH permits did not have the necessary capital or capacity to manage a concession, so they effectively "sold" their permits to HPH concessionaires. As a result the farmers' groups only received a small fee ranging from Rp. $40,000-60,000$ per $\mathrm{m}^{3}$ of wood harvested. This fee was then distributed evenly between all the members of the farmers' group, once a coordination fee of around Rp. 5,000 per $\mathrm{m}^{3}$ had been subtracted, members each received between Rp. 35,000 - 55,000 per $\mathrm{m}^{3}$. Taking a market rate for timber such as Meranti ${ }^{16}$ of around Rp.700,000 per $\mathrm{m}^{3}$. This meant that communities, represented by (all male) farmers' groups generally received less than $9 \%$ of the market value of timber logged on customary land.

Neither the national nor the district policy on smallscale permits regulated or provided guidance on management and profit sharing arrangements. Instead, a letter of agreement, drafted by investors and acknowledged by regional officials, set out the binding terms and conditions of partnerships between farmers' groups and commercial companies.

\section{Insufficient Enforcement and Monitoring}

In line with national legislation, the district policy stipulated that timber harvesting on HPHH 100 ha concessions should be done manually. The heaviest machinery permitted was a chainsaw ${ }^{7}$. However, in practice, nearly all logging was done with heavy machinery: tractors, trucks, and so forth.

The national and district regulations were also intended to limit environmental damage, but they were not enforced because the district does not have the capacity, for example, to control the use of heavy equipment. It is important to note that on concessions allocated to communities with damar tebok rights, trees that have been tapped are automatically less valuable because there are holes in the wood. As a result, a form of selective harvesting has been used. In general, only non-resin producing species, with higher commercial value have been logged.

HPHH holders whose area lies within production forests or dry, agricultural lands (not slated for conversion), are legally obliged to replant the areas 
with the same number of trees they have harvested ${ }^{18}$. However, no concession areas were replanted, in part because commercial partners managed the logging, not the farmers' groups holding the permit. As they have long-term ownership claims on the land, farmers' groups have more incentive to undertake replanting; but they lack skills, funds and capacity. Permits are only valid for one year, enough time to carry out logging. Once the permit has expired, there is little incentive for commercial investors to undertake planting or regeneration activities.

\section{Central Government Revokes Policy}

The Ministry of Forestry revoked the district heads' right to issue $\mathrm{HPHH} 100$ ha permits from 1 March $2002^{19}$. However, Sintang officials extended existing licences at least until December 2003. The central government has now limited the district's authority to issuing permits for harvesting forest products amounting to less than $20 \mathrm{~m}^{3}$ of timber or 20 tons of non-timber products per year. The limited harvest is intended to meet only subsistence needs and the timber cannot be sold.

The new policy is very unpopular with local stakeholders, who now have no opportunity to control or profit from any commercial logging activities in their area.

\section{Conclusions and Recommendations}

Our research identified important lessons from the impacts of the HPHH 100 ha permit system in Sintang.

The first is related to legal access to resources. The criteria for determining which groups were eligible to apply for a permit were too exclusive, and did not take sufficient account of local communities' different social positions, real needs or capacities. As a result, the policy has not improved levels of access to forest resources for the most disadvantaged local people.

Our stakeholder analysis shows that benefits went largely to entrepreneurs, elites and government officials ${ }^{20}$. In addition, the failure to monitor and enforce environmental protection standards in both $\mathrm{HPHH} 100$ ha and large-scale HPH concessions accelerated forest degradation. Consequently local people whose lives depend on forest resources face continuing hardships.

Second, due to the commercial scale and rapid pace of forest exploitation, local people lacked the capacity to compete with commercial firms with capital, equipment and experience. As An HPHH 100 ha licence was only valid for a year, farmers' groups competed with each other to secure partners capable of logging the area very quickly, and with good contacts in the wood marketing and processing industries. In some cases this lead to local conflicts

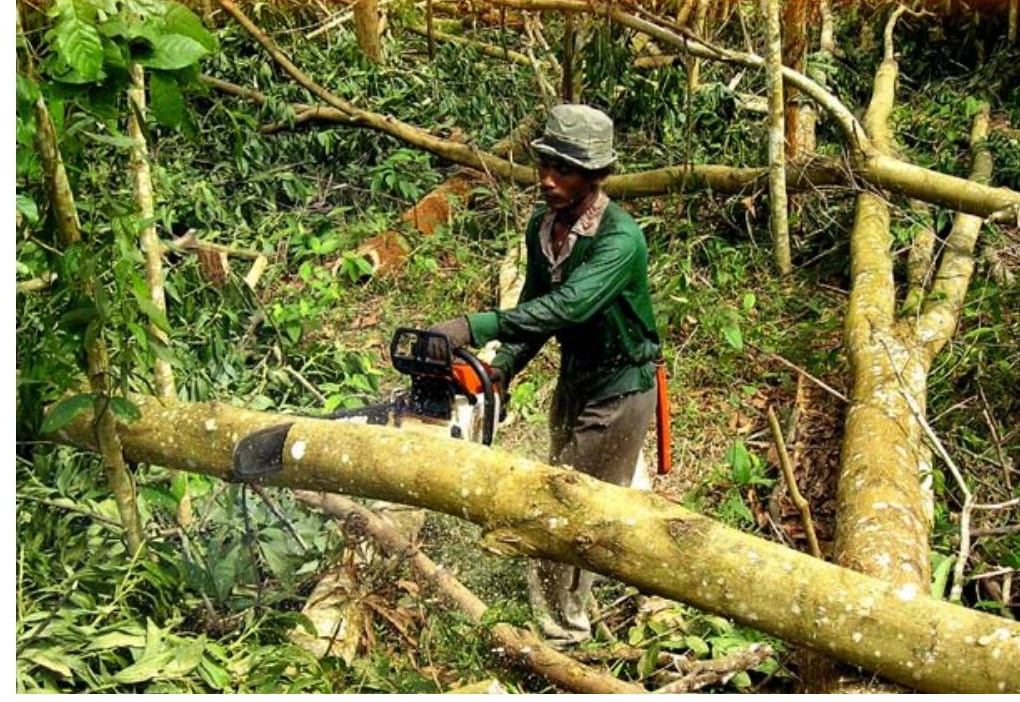

Logging harvesting by local people in East Kalimantan. (Photo By Romain Pinraid)

between communities. It also meant that there was limited if any time spent planning the long-term management of the land under concession.

Third, the central and district governments' regulations did not take sufficient account of local people's capacity. The HPHH 100 ha policy drastically changed local people's roles - from being observers to being actors. Technically and culturally, the changes were introduced too quickly, giving little time for people to prepare themselves to work with the new system, especially the most disadvantaged groups. Consequently, only local elites and government officials with relevant skills who were well connected to local networks and had links with forest entrepreneurs were able to benefit substantially.

These three lessons suggest there is a need for the central government to work with district governments to reformulate forest management policies, so that they are people-based and better suited to local people's capacity. The government should take account of traditional forest uses. It should also define clear criteria and indicators for community-based forest management and partnership agreements. This will enhance local capacity for forest management and ensure that any partnership schemes result in equitable benefit sharing.

In the future, local people need more secure access to forest resources. The previous policy only gave certain community members access to short-term financial gains from exploiting their remaining forest resources. Future policy needs to provide legal recognition and support for local communities; to encourage and support activities that can increase their income and sustain what is left of forest resources. It is essential that local people be given meaningful roles in planning, implementing, and evaluating forestry programmes. This could include involving local people in forest land planning; land rehabilitation and 
cultivating forest seedlings. Both the national and the district governments could do more to focus their policies on serving stakeholders' needs and developing prosperity, social justice and sustainable forest resources for the future.

\section{Bibliography}

Alqadrie, Syarif I., Anshari, Gusti., Budiarto, Tri. Ngusmanto, Zulkifli, Abidin, Erdi., dan Afifudin. 2004. (in preparation) Analisis Kebijakan Sektor Kehutanan dalam Era Otonomi Daerah di Kabupaten Sintang, Kalimantan Barat. Laporan Penelitian. CIFOR bekerjasama dengan S2 IImu Sosial Untan dan Yayasan Konservasi Borneo

Budiarto, Tri., Setyarso, Agus., Slamet, Elaine P., and Anshari, Gusti. 2004 (in press). Illegal Logging, Livelihood Security and Conflict: The Case of West Kalimantan. EDSP Working Paper No. 4. AldephyResearch. Berlin

Holmes, D. 2000. Deforestation in Indonesia: A view of the situation in 1999. Word Bank Draft Report. Jakarta, Indonesia.

\section{Endnotes}

${ }^{1}$ The DPRD approved the proposed policy on licensing Forest Product Harvesting Rights in an official letter to the Bupati (No. 522/270/DPRD/1999)

2 SK Bupati Sintang No. 19/1999

${ }^{3}$ SK Bupati Sintang 19/1999 Articles 14

${ }^{4}$ SK Bupati Sintang 19/1999 Articles 14:2

${ }^{5}$ IPK permits differ from HPH permits in that the land can be converted to other uses (oil palm plantation; agriculture; etc) after clear felling. HPH concession areas must be replanted after logging.

${ }^{6}$ SK Bupati Sintang No. 19/1999 Article 17

${ }^{7}$ SK Bupati Sintang No. 19/1999 Article 15:1

8 For a full account of the district authorities' domination of the permit system; and other stakeholders' ability to influence the process, see Decentralization and Forests in Indonesia Case Study 11, CIFOR, 2004 (forthcoming)

9 Kapuas Hulu district is the study site of our first round of research conducted in 2002 and 2003 by the University of Tanjungpura and CIFOR

${ }^{10}$ In Sintang, there were two active concessions who set up partnerships with communities to access timber under the HPHH policy

${ }^{11}$ SK Bupati No. 19/1999 Article 8:1

${ }^{12}$ SK Bupati No. 19/1999 Article 2:1

${ }^{13}$ SK Bupati No. 19/1999 Article 18:1-2

${ }^{14}$ National Regulation (PP) No 51/1998 on PSDH (IHH) payment mechanisms

${ }^{15}$ The district governments is West Kalimantan expected to receive Rp. 9,6 billion from PSDH in 2003. The actual payment made by the centre was only Rp. 5.7 billion

${ }^{16}$ Meranti is the most commonly logged timber in West Kalimantan

${ }^{17}$ SK Bupati No 19/1999 Article 15:1-2

${ }^{18}$ SK Bupati No 19/1999 Article 17:1

19 Ministerial Decree No. 541/Kpts-II/2002, Government Regulation (PP)34/2002, Ministerial Decree No. 6886/Kpts-II/2002 and Ministerial Decree No. $05.1 /$ Kpts-II/2000

${ }^{20}$ See footnote 13

Gusti Z. Anshari and Zulkifli of Borneo Conservation Foundation; Syarief Alqadrie, Ngusmanto and Erdi Abidin of Tanjungpura University; Tri Budiarto and Afifudin of West Kalimantan Provincial Forestry Services; and Siân McGrath of CIFOR prepared this Decentralisation Brief drawn from the report: The Complexity of Forest Resource Management in the era of Decentralization - a case study of Sintang district, West Kalimantan. This work has been funded by ACIAR and DFID under the project: Can Decentralisation Work for Forests and the Poor? The opinions expressed herein are those of the authors and do not necessarily reflect the views of funding agency.

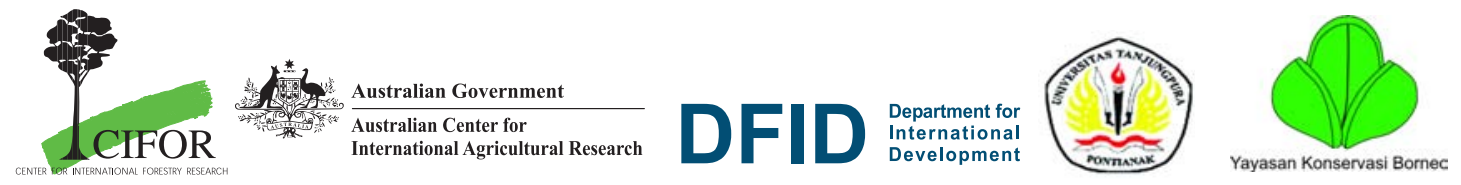

Center for International Forestry Research, CIFOR

Office: Jalan CIFOR, Situ Gede, Sindang Barang, Bogor Barat 16680, Indonesia. Mailing: P.O. Box. 6596 JKPWB, Jakarta 10065, Indonesia
Tel: +62(251) 622622 Fax: +62(251) 622100

E-mail: cifor@cgiar.org Website: www.cifor.cgiar.org

Front page photos by: R. Pinraid and C. Cossalter

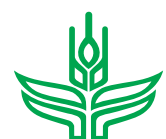

F U T UR E HAR $/ /$ EST 